\title{
過去事象から安全の本質を学ぶ
}

\section{辻 村厚}

東海旅客鉄道株式会社執行役員安全対策部長

鉄道を安全に運行するためには，乗務員や駅係員といった運輸系統，鉄道車両を保守する車両系統，線 路や橋梁等の土木構造物を保守する施設系統等, 電力や信号通信設備を保守する電気系統, 様々な系統の 関係者が, それぞれの役割を確実に果たす必要があり, 1 年365日, どこかで誰かが必ず仕事をしています. これまで，鉄道を守る仕事に従事する関係者の安全を守るため，様々な設備，ルール，基本動作等が整え られ, 更に関係者の不断の努力があり, 当社の労働災害の件数は確実に減少してきました. しかしながら, ゼロになっていないのが現状です。

これを限りなくゼロに近づけるため，当社では年度毎に安全に関する重点方針として「安全の取り組み 方針」を定め, 関係者全員が同じ認識に基づき, 安全を最優先に仕事を進めています。令和 2 年度の方針 は3本の柱から構成されています。

1つめの柱が，「安全最優先の文化の醸成」です．安全の土台となるこの文化を醸成して各職場に根付 かせるため, 当社では平成25年度から「安全のための本質を探究する運動」に取り組んでいます．当社 で発生した労働災害の多くが，ルールや基本動作に対する理解不足や，納得感が得られないまま形だけが 踏襲（場合によっては, その形さえも変容）されたことに起因していました．この課題を解決するには, 関係者全員がルールや基本動作の重要性や意義, すなわち「本質」を十分に理解し, 納得して実践する必 要があります。その際のキーワードが「3つのど」です。これは, 「1)どうして」という問いかけにより ルール等が定められた歴史，背景に気づき，「(2)どうなる」によりルール通りに実施しなかった時の影響 や結果を想像することで, ルールや基本動作の本質の理解を促します。すなわち, 過去事象, つまり先人 の苦い経験という貴重な歴史に学ぶということです。さらに, (1)と(2)の結果を踏まえたうえで,「(3)どう する」により，自らがルールや基本動作を正しく実行することを意識し，工夫するという流れです．

2つめの柱が,「一人ひとりの安全の実行力の向上」です.ルールや基本動作の本質が理解できていても, 実際の現場でこれが実行できなければ意味がありません，すなわち，「どうすればできる」という観点で の取り組みが重要となります，そこで，関係者の一人ひとりが，自らの意志で実直にやるべきことをやり 遂げることを徹底するとともに，リスクや变化に対する感度を高め, 確実に対処するため, 様々な安全教 育・訓練の充実を図っています。特に,「訓練以上のことは現場では実践できない, 訓練は貴重な経験の場」 という認識のもと，不測の事態や異常時の対応も含めた実践で役立つ訓練を工夫して行っています．例え ば，あえてシナリオを用意しないブラインド型訓練，過去の失敗を追体験できる訓練，災害の受傷を模擬 的に経験する体感訓練やVRを活用した訓練等がこれに相当します。

3つめの柱が,「安全に関する仕組みの強化」です。安全の確保には，一人ひとりの意識の徹底はもち ろん, 組織全体の仕組みの強化も必要です。そのために重要なのが,「視るべき目」をもって現場の実態 を把握し, いつでも, どこでも, 誰もが正しい仕事ができる状態に, 常に仕組みを改善していくことです. 例えば，時代の経過や環境の変化等に伴い実態に合わなくなったルールや取り扱いを見直し，常に安全に 関する仕組みを検証，改善しています．また，フェールセーフや予兆管理の観点から，新しい技術の導入 も積極的に進めてきたいと思います.

新型コロナウィルスの影響で, 社会全体が未曽有の事態となっています，今後，これまでの常識が続く ことはないでしょう，そのような状況下において，今までと同様の安全を確保するには，従前の成功体験 に胡坐をかくことなく, 社会情勢や時代の変化に応じて組織や仕組みをシフトチェンジしていく必要があ ります。組織の根源が「人」であるように, 安全確保のための取り組みの根源もまた「人」です。「草莽 
崛起（そうもうくつき）」.これは私の敬愛する吉田松陰が述べた言葉の一つですが，これまで鉄道の安全 を支えてきた関係者の一人ひとりが，今まで以上に安全に対する高い志を持ち，シフトチェンジを実現す る原動力になることが，重要だと思います． 